\title{
PENGARUH PERASAN DAUN BELIMBING WULUH (Averrhoa bilimbi) TERHADAP PERTUMBUHAN BAKTERI Escherichia coli PATOGEN
}

\author{
Fitrotin Azizah ${ }^{1}$ \\ 1) Prodi D3 Analis Kesehatan, FIK, Universitas Muhammadiyah Surabaya \\ ichafitrotin@gmail.com
}

Tangal Submit:

27 November 2017

Tanggal Review:

13 Desember 2017

Tanggal Publish Online:

19 Desember 2017

\begin{abstract}
Averrhoa bilimbi is one of the plants that can be used as an antibacterial, good flowers, stems, leaves and stems have benefits and efficacy. Chemical constituents of the leaves starfruit are tannins, flavonoids, saponins. The active ingredient in the leaves starfruit is tannin. Escherichia coli is a bacterium that causes diarrhea. From the above discussion, the authors raised the theme of Influence starfruit juice of the leaves on the growth of pathogenic E. coli bacteria. Formulation of the problem researchers is whether there is influence starfruit juice of the leaves on the growth of Escherichia coli pathogens. This study aims to determine the concentration that could inhibit and kill Escherichia coli. This research is experimental. The sample used is leaf green starfruit not so young in a fresh state taken in the area around the boarding author Sutorejo 11B stay. In this study, the sample size for each treatment as much as $3100 \%, 90 \%$, $80 \%, 70 \%, 60 \%, 50 \%, 40 \%, 30 \%, 20 \%, 10 \%$ and C (control). Independent variables are starfruit juice of the leaves, while the dependent variable growth of Escherichia coli. When the study carried out in January and July 2012. Data on the effect of starfruit juice of the leaves on the growth of Escherichia coli tested by laboratory examination and data collection techniques using ChiSquare 0:05. Based on the results it appears that at a concentration of $100 \%$ and $90 \%$ were able to kill the bacteria Escherichia coli, whereas the inhibitory power ranging from a concentration of $80 \%$, $70 \%, 60 \%, 50 \%, 40 \%, 30 \%, 20 \%, 10 \%$. From Chi-Square test was obtained $\lambda 2$ count $<$ of $\lambda 2$ table. From this it turns out there leaves starfruit juice effect on the growth of Escherichia coli pathogenic bacteria.
\end{abstract}

Keywords $\quad$ : Leaves starfruit, E. Coli

\section{PENDAHULUAN}

Penyakit infeksi merupakan penyakit yang banyak diderita masyarakat Indonesia sejak dulu, diantaranya adalah infeksi usus (diare). Diare adalah suatu gejala klinis dari gangguan pencernaan (usus) yang ditandai dengan bertambahnya frekuensi defekasi lebih dari biasanya dan berulang-ulang yang disertai adanya perubahan bentuk dan konsistensi feses menjadi lembek atau cair.

Salah satu penyebab terjadinya diare antara lain karena infeksi kuman penyebab diare. Naim (2011) menginventarisasi 12 jenis 
bakteri, yaitu: Stapyilococcus aureus, Bacillus cereus, Clostridium perferingens, Escherichia coli, Vibrio cholerae, Shigella sp, Clostidium difficile, Campylobacter jejuni, Yersinia enterolitica, Klebsiella pnemoniae, Vibrio haemoliticus. Namun menurut Dzulkarnain (1996) kasus diare di Indonesia lebih sering disebabkan oleh Staphylococcus aureus, Escherichia coli, Vibrio cholerae, Salmonella $s p$.

Pengobatan diare bisa dilakukan dengan pemberian obat-obat kimia dan obatobat tradisional. Penggunaan obat-obat tradisional memiliki kelebihan, yaitu meminimalkan efek samping yang ditimbulkan. Seiring dengan perubahan zaman penggunaan tumbuh-tumbuhan sebagai obatobatan telah mengalami perkembangan yakni yang bersifat empiris ke ilmiah. Senyawa metabolit sekunder selain sebagai obat tradisonal juga dapat digunakan sebagai antibakteri. Penggunaan antibakteri sintetik lebih memberikan efek samping yang lebih berbahaya dibandingkan dengan antibakteri yang terbuat dari obat-obat tradisional.

Averrhoa bilimbi adalah salah satu tanaman yang dapat digunakan sebagai antibakteri. Tanaman belimbing wuluh ini baik bunga, buah, daun bahkan batangnya mempunyai manfaat dan khasiat. Kandungan kimia dari Averrhoa bilimbi adalah tanin, saponin, glukosida, sulfur, asam format, peroksida (Anonim, 2007). Pada daun belimbing wuluh mengandung tanin, saponin, flavonoid. Bahan aktif pada daun buah belimbing wuluh adalah tanin. Tanin ini dapat digunakan sebagai astringent baik untuk saluran pencernaan maupun kulit dan dapat juga sebagai obat diare serta anti bakteri (Wijayakusuma, 2006).

Pada penelitian sebelumnya (Zakaria, 2007) ekstrak kloroform daun belimbing wuluh mempunyai aktivitas antibakteri terhadap bakteri gram negatif seperti Salmonella thypi, Citrobacter fuendii, Aeromonas hydropila, dan Proteus vulgaris dengan Konsentrasi Hambat Minimum (KHM) sebesar $50 \mathrm{mg} / \mathrm{mL}$. Berdasarkan penelitian sebelumnya maka perlu dilakukan penelitian atau pengujian apakah perasan daun belimbing wuluh juga berpengaruh dalam pertumbuhan bakteri Escherichia coli. Mengingat Escherichia coli juga termasuk golongan gram negatif famili Enterobactericeae.

Dari uraian diatas maka peneliti mengambil tema "Pengaruh Perasan Daun Belimbing Wuluh (Averrhoa bilimbi) terhadap pertumbuhan Escherichia coli Patogen". Rumusan Masalah dalam penelitian ini adalah Apakah ada pengaruh perasan daun belimbing wuluh terhadap pertumbuhan bakteri Escherichia coli? Dan Berapakah konsentrasi perasan daun belimbing wuluh yang dapat menghambat pertumbuhan bakteri Escherichia coli?. Tujuan Penelitian adalah Untuk mengetahui pengaruh perasan daun belimbing wuluh terhadap pertumbuhan bakteri Escherichia coli patogen dan Untuk mengetahui pada konsentrasi terkecil yang 
sudah dapat menghambat pertumbuhan Escherichia coli patogen.

\section{METODE PENELITIAN}

Jenis penelitian ini adalah eksperimental dengan tujuan untuk mengetahui pengaruh perasan daun belimbing wuluh terhadap pertumbuhan bakteri Escherichia coli. Sedangkan untuk rancangan penelitian adalah sebagai berikut :

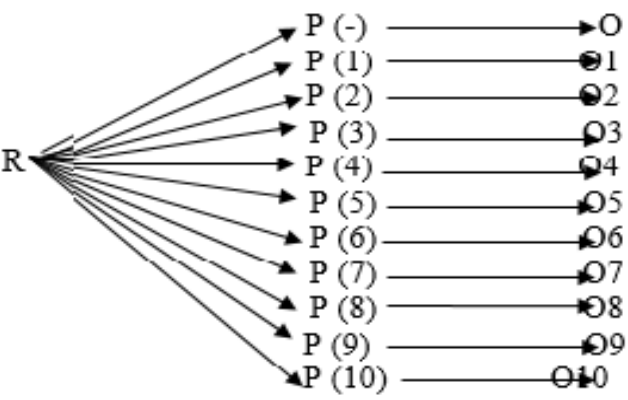

Keterangan :

$\mathrm{R}$ : Random

P (-) : Perlakuan tanpa diberi perasan daun belimbing wuluh

P (1) : Perlakuan dengan pemberian perasan konsentrasi $100 \%$

$\mathrm{P}(2)$ : Perlakuan dengan pemberian perasan konsentrasi $90 \%$

$\mathrm{P}(3)$ : Perlakuan dengan pemberian perasan konsentrasi $80 \%$

$\mathrm{P}(4)$ : Perlakuan dengan pemberian perasan konsentrasi $70 \%$

$\mathrm{P}(5)$ : Perlakuan dengan pemberian perasan konsentrasi $60 \%$

P (6) : Perlakuan dengan pemberian perasan konsentrasi $50 \%$

P (7) : Perlakuan dengan pemberian perasan konsentrasi $40 \%$

P (8) : Perlakuan dengan pemberian perasan konsentrasi $30 \%$

$\mathrm{P}(9)$ : Perlakuan dengan pemberian perasan konsentrasi $20 \%$

$\mathrm{P}(10)$ : Perlakuan dengan pemberian perasan konsentrasi $10 \%$
O (-) : Observasi pertumbuhan Escherichia coli pada perlakuan tanpa pemberian perasan

O (1) : Observasi pertumbuhan Escherichia coli pada perlakuan pemberian perasan konsentrasi $100 \%$

O (2) : Observasi pertumbuhan Escherichia coli pada perlakuan pemberian perasan konsentrasi $90 \%$

O (3) : Observasi pertumbuhan Escherichia coli pada perlakuan pemberian perasan konsentasi $80 \%$

O (4) : Observasi pertumbuhan Escherichia coli pada perlakuan pemberian perasan konsentrasi $70 \%$

O (5) : Observasi pertumbuhan Escherichia coli pada perlakuan pemberian perasan konsentrasi $60 \%$

O (6) : Observasi pertumbuhan Escherichia coli pada perlakuan pemberian perasan konsentrasi $50 \%$

O (7) : Observasi pertumbuhan Escherichia coli pada perlakuan pemberian perasan konsentrasi $40 \%$

O (8) : Observasi pertumbuhan Escherichia coli pada perlakuan pemberian perasan konsentrasi $30 \%$

O (9) : Observasi pertumbuhan Escherichia coli pada perlakuan pemberian perasan konsentrasi $20 \%$

O (10) : Observasi pertumbuhan Escherichia coli pada perlakuan pemberian perasan konsentrasi $10 \%$

Dalam penelitian ini populasinya adalah bakteri Escherichia coli yang ditanam di media EMB (Eosin Methyline Blue). Sampel yang digunakan dalam penelitian ini adalah Bakteri Eschericia coli pada masingmasing konsentrasi yang dilihat 
pertumbuhannya pada media EMB (Eosin Methyline Blue) setelah diinkubasi selama 24 jam. Besar sampel dalam penelitian ini adalah 3.

Penelitian dilaksanakan di daerah Sutorejo Surabaya, sedangkan pemeriksaan dilakukan di laboratorium Mikrobiologi Prodi D3 Analis Kesehatan Fakultas Ilmu Kesehatan Universitas Muhammadiyah Surabaya. Penelitian ini dilaksanakan pada bulan Januari sampai bulan Juli 2012, sedangkan pemeriksaan dilaksanakan pada bulan April sampai bulan Mei 2012.

Variabel bebas dalam penelitian ini adalah Perasan daun belimbing wuluh, Perasan daun belimbing wuluh dikategorikan menjadi berbagai macam konsentrasi, yaitu: $100 \%, 90 \%, 80 \%, 70 \%, 60 \%, 50 \%, 40 \%$, $30 \%, 20 \%, 10 \%$, dan 0\% (kontrol). Variabel terikatnya adalah Pertumbuhan bakteri Escherichia coli. Pertumbuhan bakteri Escherichia coli adalah Escherichia coli yang tumbuh pada media EMB (Eosin Methyline Blue) pada masing-masing konsentrasi dalam skala nominal yang dikategorikan menjadi positif (+) dan negatif (-). Dimana positif (+) jika terjadi pertumbuhan bakteri Escherichia coli, sedangkan negatif (-) jika tidak terjadi pertumbuhan bakteri Escherichia coli. Variabel Kontrolnya antara lain Volume suspensi bakteri, lama inkubasi.

Data pertumbuhan bakteri Escherichia coli diperoleh dengan cara observasi tidak langsung, yaitu dengan melalui uji Laboratorium. Pemeriksaan daya hambat bakteri Escherichia coli ini menggunakan metode Dilusi.

Prinsip Pemeriksaan, Senyawa antibakteri yang ada pada perasan daun belimbing wuluh diencerkan hingga diperoleh beberapa macam konsentrasi, kemudian masing-masing konsentrasi ditambahkan suspensi bakteri uji dalam media cair. Perlakuan tersebut akan di inkubasi dan diamati ada atau tidaknya pertumbuhan bakteri yang ditandai dengan terjadinya kekeruhan. Larutan uji senyawa antibakteri pada kadar terkecil yang terlihat jernih tanpa adanya pertumbuhan bakteri uji, ditetapkan sebagai Kadar Hambat Minimum (KHM) atau MIC (Minimum inhibition concentration) (Pratiwi, 2008). Untuk menegaskan bahwa bakteri Escherichia coli tumbuh atau tidak, dilakukan tes penegasan dengan cara : hasil dari tabung pada tes uji tersebut ditanam dimedia EMB (Eosin Methyline Blue). Lalu diinkubasi pada suhu $37^{\circ} \mathrm{C}$ selama 24 jam.

Alat-Alat yang digunakan antara lain Timbangan, Gelas arloji, Tabung Reaksi, Gelas ukur, Pengaduk, Rak tabung, Pipet pasteur, Api spirtus, kaki tiga, Blender, Filler, Erlenmeyer, Ose, Autoclave, Plate, Pipet ukur, Tabung sentrifuge, Lidi kapas steril. Bahan Pemeriksaan meliputi Perasan daun belimbing wuluh, Suspensi kuman Escherichia coli. Reagen dan Media Pemeriksaan meliputi $\mathrm{NaOH} 0.1 \mathrm{~N}, \mathrm{HCL} 0.1 \mathrm{~N}, \mathrm{BaCl}_{2} 1 \%, \mathrm{H}_{2} \mathrm{SO}_{4}$ $1 \%, \mathrm{Pz}$ Steril, Aquadest steril, Media NA (Nutrient Agar), Media EMB (Eosin Methyline Blue). 
Pembuatan suspensi kuman sesuai dengan metode Mc.Farlan I, Prosedur Pembuatan Konsentrasi Perasan Daun Belimbing Wuluh, Mencuci daun sampai bersih dan yang terakhir dicuci dengan aquadest steril, Menimbang daun belimbing wuluh yang masih muda sebanyak 100 gram, Menghaluskan daun sampai halus. Sebelumnya mortir diusap dengan alkohol agar steril, Menyaring daun yang sudah dihaluskan tadi (juice) dengan kasa berlapis yang steril. Menyentrifuge kembali perasan tadi ditabung sentrifuge yang steril sehingga didapatkan perasan yang benar- benar jernih. Mengambil 1 mata ose perasan yang sudah jernih secara steril, kemudian menanamnya ke media NAP, dengan cara menggoreskannya dipermukaan media, Inkubasi selama 24 jam $37^{\circ} \mathrm{C}$, Mengamati hasilnya, jika tidak terjadi pertumbuhan kuman berarti perasan daun belimbing wuluh tadi sudah benar benar steril. Namun jika pada media NAP terdapat pertumbuhan kuman berarti perlu dilakukan proses tindalisasi, Menanam kembali perasan daun belimbing wuluh yang sudah melalui proses tindalisai di media NAP da menginkubasinya selama 24 jam pada suhu $37^{\circ}$ C. Membuat konsentrasi 100\%, 90\%, $80 \%, 70 \%, 60 \%, 50 \%, 40 \%, 30 \%, 20 \%$, dan $10 \% \mathrm{Pz}$ steril.

\section{Prosedur Pemeriksaan Sampel}

a. Hari pertama pemeriksaan, Menyiapkan alat dan bahan yang dibutuhkan, Menyalakan api spirtus dengan korek api. Masing-masing tabung diberi label sesuai dengan konsentrasinya, yaitu konsentrasi 100\%, 90\%, $80 \%, 70 \%, 60 \%, 50 \%, 40 \%, 30 \%, 20 \%, 10 \%$ dan $0 \%$ atau $\mathrm{C}$ (Control). Mengambil suspensi kuman Escherichia coli sebanyak 1 mata ose, dengan ose yang sudah distandartkan. Dengan ketentuan 1 mata ose sama dengan 1 juta kuman. Kemudian menanamnya ke konsentrasi 100\%. Masing - masing konsentrasi diperlakukan sama halnya seperti konsentrasi 100\%. Semua perlakuan dilakukan secara steril dekat dengan api. Menutup kembali tabung dengan kapas berlemak, Inkubasi pada suhu $37^{\circ} \mathrm{C}$ selama 24 jam.

b. Hari kedua, Mengamati masing-masing tabung, apakah terjadi kekeruhan atau tidak. Mengambil Konsentrasi terkecil yang mulai terlihat keruh, dan menguji kembali ke media EMB dengan tujuan memastikan apakah kuman tersebut adalah Escherichia coli. Memanaskan ose bulat di atas nyala api spirtus, mengambil 1 mata ose kuman yang ada pada konsentrasi terkecil tadi. Menanamnya di media EMB dengan cara menggoreskannya dipermukaan media. Inkubasi kembali pada suhu $37^{\circ} \mathrm{C}$ selama 24 jam.

c. Hari ketiga, Mengamati hasilnya pada media EMB apakah terbentuk koloni yang mengidentifikasikan kuman tersebut adalah Escherichia coli. Mencatat konsentarasi terkecil tadi sebagai daya hambat pertumbuhan kuman. Mencatat hasil yang di amati sebagai data. 


\section{HASIL PENELITIAN}

Berdasarkan

pemeriksaan

pertumbuhan bakteri Escherichia coli dalam perasan daun belimbing wuluh (Averrhoa bilimbi) yang dilakukan di Laboratorium Mikrobiologi Prodi D3 Analis Kesehatan Fakultas Ilmu Kesehatan Universitas Muhammadiyah Surabaya didapatkan hasil sebagai berikut :

Tabel 1. Hasil Pertumbuhan E.coli pada masing masing konsentrasi

\begin{tabular}{|c|c|c|c|c|c|c|c|c|c|c|c|c|}
\hline \multirow{3}{*}{$\mathrm{N}$} & \multirow{3}{*}{$\begin{array}{c}\text { Kede. } \\
\text { Samp. } \\
\text { el }\end{array}$} & \multicolumn{11}{|c|}{$\begin{array}{c}\text { Konsentrasi Rerasgn daun belimbing wuluh + kuman } E \text { coli } \\
\text { (\%) }\end{array}$} \\
\hline & & 10 & 9 & 8 & 7 & 6 & 5 & 4 & 3 & 2 & 1 & $\mathrm{C}$ \\
\hline & & 0 & 0 & 0 & 0 & 0 & 0 & 0 & 0 & 0 & 0 & (+ \\
\hline 1 & & & & & & & & & & & & \\
\hline 1 & A & + & + & - & - & - & - & - & - & - & - & - \\
\hline 2 & $B$ & + & + & - & - & - & - & - & - & - & - & - \\
\hline & & & & & & & & & & & & \\
\hline 3 & $C$ & + & + & 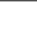 & 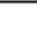 & . & - & 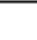 & . & 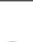 & . & 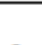 \\
\hline & $c$ & + & + & - & - & - & - & - & - & - & - & - \\
\hline & mlah & 3 & 3 & 0 & 0 & 0 & 0 & 0 & 0 & 0 & 0 & 0 \\
\hline
\end{tabular}

Keterangan :

Positif (+) : Jernih

Negatif (-) : Keruh

Berdasarkan tabel hasil penelitian di atas dapat diperoleh data bahwa pada konsentrasi $100 \%$ dan $90 \%$ perasan daun belimbing wuluh terlihat jernih, sedangkan pada konsentrasi 80\%, 70\%, 60\%, 50\%, 40\%, $30 \%$, 20\%, dan $10 \%$ perasan daun belimbing wuluh setelah ditanami kuman E.coli terlihat keruh.

Untuk memastikan apakah konsentrasi perasan daun belimbing wuluh tersebut mampu memghambat atau tidak, masingmasing konsentrasi ditanam di media EMB.
Dibawah ini adalah tabel hasil EMB yang sudah ditanami Konsentrasi perasan dengan kuman.

Tabel 2. Pertumbuhan Bakteri di media EMB

\begin{tabular}{|c|c|c|c|c|c|c|c|c|c|c|c|c|}
\hline \multirow[t]{2}{*}{ No } & \multirow{2}{*}{$\begin{array}{c}\text { Ko } \\
\text { de } \\
\text { sa } \\
\text { mp } \\
\text { el }\end{array}$} & \multicolumn{10}{|c|}{$\begin{array}{c}\text { Pertumbuhan Escherichia coli di media EMB pada } \\
\text { masing-masing konsentrasi }\end{array}$} & \multirow{2}{*}{$\begin{array}{c}\text { Ket } \\
\%\end{array}$} \\
\hline & & 100 & 90 & 80 & 70 & 60 & 50 & 40 & 30 & 20 & 10 & \\
\hline 1. & A & - & - & + & + & + & + & + & + & + & + & $\begin{array}{l}\mathrm{MIC} \\
80 \%\end{array}$ \\
\hline 2. & B & - & - & + & + & + & + & + & + & + & + & $\begin{array}{l}\mathrm{MIC} \\
80 \% \\
\end{array}$ \\
\hline 3. & $\mathrm{C}$ & - & - & + & + & + & + & + & + & + & + & $\begin{array}{l}\mathrm{MIC} \\
80 \%\end{array}$ \\
\hline $\begin{array}{l}\text { Ket } \\
\text { Pos } \\
\text { Neg }\end{array}$ & if $(-$ & & & lak & rjac & pert & nbu & $\begin{array}{l}\text { xteri } \\
\text { an } b\end{array}$ & kteri & & & \\
\hline
\end{tabular}

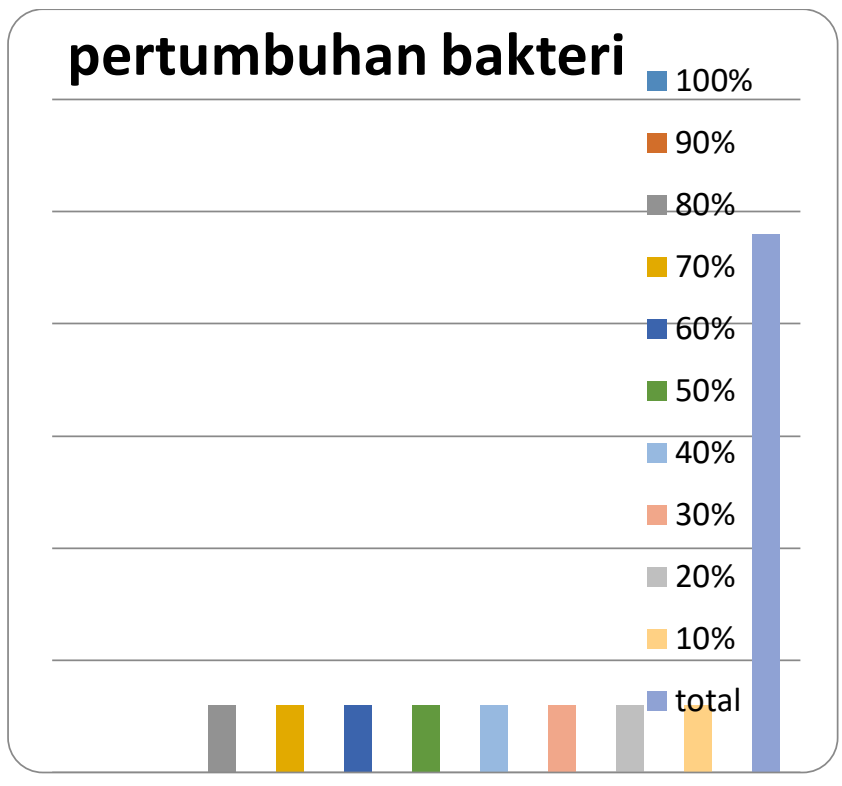

Gambar 1. Pertumbuhan Escherichia coli pada media EMB

\section{PEMBAHASAN}

Berdasarkan hasil penelitian yang telah dilakukan dapat diketahui bahwa perasan daun belimbing wuluh pada konsentrasi $100 \%$ dan $90 \%$ mempunyai kemampuan membunuh bakteri Escherichia coli patogen, sedangkan pada konsentrasi $80 \%$ mempunyai daya 
hambat (MIC) pertumbuhan bakteri

Escherichia coli.

Hasil positif pada penelitian yang berarti menghambat pertumbuhan Escherichia coli dapat disebabkan karena adanya zat antibakteri dalam perasan yaitu : tanin, flavonoid, asam format, sulfur, dan kalium sitrat. Zat aktif yang berperan pada daun belimbing wuluh adalah tanin.

Menurut Okuda (2004) tanin berpotensi sebagai antibakteri, sedangkan penelitian Hayati (1996) membuktikan bahwa tanin mempunyai kemampuan menghambat pertumbuhan bakteri seperti Escherichia coli. Efek antibakteri tanin antara lain adalah menghambat sintesis dinding sel bakteri, menghambat sistem genetik, penghambat enzim dan mendenaturasi protein sehingga dinding sel mengalami kerusakan karena penurunan permeabilitas. Perubahan permeabilitas membran sitoplasma memungkinkan terganggunya transportasi ion - ion organik yang penting kedalam sel sehingga berakibat terhambatnya pertumbuhan bahkan hingga mematikan sel. Tanin merupakan senyawa fenolik. Golongan senyawa ini berdaya aksi dengan cara mendenaturasi dalam rentang waktu sekitar 10 - 30 detik. Umumnya digunakan dalam larutan air dalam konsentrasi $0.1-5 \%$. Aplikasi desinfektan dilakukan untuk virus, spora, tetapi tidak baik digunakan untuk membunuh beberapa jenis bakteri gram positif dan ragi (Rahman AF, 2009).
Pada konsentrasi $100 \%$ dan $90 \%$ mampu menghambat pertumbuhan bakteri dikarenakan pada konsentrasi tersebut kandungan kimianya tidak terlalu encer atau bisa dikatakan masih kental. Sehingga kandungan kimianya lebih banyak dibandingkan dengan konsentrasi 80\%, 70\%, $60 \%, 50 \%, 40 \%, 30 \%, 20 \%$ dan $10 \%$ yang sudah melalui proses pengenceran lebih banyak.

Konsentrasi terkecil yang sudah mampu menghambat pertumbuhan bakteri adalah $80 \%, 70 \%, 60 \%, 50 \%, 40 \%, 30 \%, 20 \%$ dan $10 \%$. Hal ini dikarenakan kandungan kimia yang ada pada konsentrasi tersebut tidak sebanyak konsentrasi $100 \%$ dan 90\%. Karena sudah melalui proses pengenceran. Dan penyebab lain adalah kadar tanin yang tidak begitu banyak pada konsentrasi tersebut. Faktor yang mempengaruhi kadar tanin adalah tanin larut dalam pelarut kimia senyawa polar, seperti alkohol, aseton, dioksan. Faktor lain adalah suhu, semakin tinggi suhunya, maka tanin akan mudah larut (Ummah, 2010).

\section{KESIMPULAN}

Dari hasil penelitian perasan daun belimbing wuluh yang telah dilakukan dapat disimpulkan bahwa Perasan daun belimbing wuluh mempunyai pengaruh terhadap pertumbuhan bakteri Escherichia coli patogen, Pada konsentrasi $90 \%$ perasan daun belimbing wuluh mempunyai kemampuan membunuh bakteri Escherichia coli (daya bunuh), sedangkan pada konsentrasi $80 \%$ perasan 
belimbing wuluh mempunyai kemampuan untuk menghambat (MIC) pertumbuhan bakteri Escherichia coli patogen.

Dari penelitian tersebut Diharapkan pada masyarakat untuk memanfaatkan tanaman sebagai obat tradisional dalam kehidupan sehari - hari, selain mudah didapatkan, relatif murah, dan tidak menimbulkan efek samping yang membahayakan. Diharapkan peneliti selanjutnya diharapkan untuk melakukan penelitian lebih lanjut untuk mendapatkan dosis yang tepat sebagai obat diare.

\section{DAFTAR PUSTAKA / BIBLIOGRAPHY}

Anonim, 2010. Belimbing wuluh Kaya Khasiat.

http://alamendah.wordpress.com/2010/0 8/15/belimbing-wuluh-averrhoa-

bilimbi-kaya-khasiat/. 08 Januari 2012

Anonim. 2011. Pengertian Perasan. http://deskripsi.com/p/peras. 23 Februari 2012

Anonim. 1996. Pengertian Ekstrak. http://deskripsi.com/p/ekstrak.

Februari 2012

Anonim. 2012. Pengertian Rebusan. http://deskripsi.com/r/rebusan. 23 Februari 2012

Anonim. 2012. Pertumbuhan Bakteri. http://biologipedia. com/2010/12/pertumbuhan-bakteri.html. 15 Maret 2012

Anonim. 2011. Koloni E.coli di Media. http://randstarteam.com/2007_12_01_ar chive.html. Diakses 17 Maret 2012
Amnur. 2008. Cikal Bakal Averhoa Bilimbi. http://Averhoabilimi.blogspot.com. 10 Januari 2012

Cahyadi, Wisnu. 2008. Analisis Aspek Kesehatan Bahan Tambahan Pangan. Edisi 2. Jakarta. Bumi aksara.

Dasuki. 1991. Sistematika Tumbuhan Tinggi. Pusat Universitas Ilmu Hayati ITB. Bandung

Darmadi, Agus. 2011. Bakteri E.coli. http://timpaltimpalcom./2011/06/bakteri-E.colisumber-energi-masa-depan.html. 10 Maret 2012

Hayati. Elok. 2011. Dibalik Mukjizat Tanaman Belimbing wuluh (Averrhoa bilimbi $l$ ) sebagai Pengawet Alami. http://elokkamilah.wordpress.com. 08 Januari 2012

Jawetz, dkk. 1996. Mikrobiologi Kedokteran. Edisi 20. Jakarta. EGC

Naim. 2004. Mekanisme Kerja Tanin. http://kerjatanin.wordpress.com. 23 Februari 2012

Naim, Nilla. 2011. Escherichia coli. http://www.nillaaprilianaim/Escherichia -coli.htm. 17 Maret 2012

Pratiwi, T. 2008. Mikrobiologi Farmasi. Bandung. Erlangga

Sudjana. 1996. Metode Statistika. Edisi 6. Tarsito Bandung

Ummah, Khoirul. 2010. Ekstraksi dan Pengujian Aktivitas Antibakteri Senyawa Tanin Pada Daun Belimbing wuluh (Averrhoa bilimbi l). http://lib.uinmalang.ac.id/thesis/fullchapter/0553000 1-masithah-khairul-u.ps. 19 Maret 2012 